\title{
ART BY TAMARA KHANUM AND ROZA KARIMOVA
}

\section{Z.S.Safarova Associate Professor, Candidate of Historical Sciences. KIEI}

\begin{abstract}
because language is a reflection of reality, and culture is an integral part of that reality, language is a simple reflection of culture. Thus, while the impact of culture on language is clear, the question of the impact of language on culture remains open for now.

Key words: culture, impact of language, methodological approaches, philosophical linguists, linguistic picture of the world.
\end{abstract}

\section{I.Introduction}

We all know how many heartfelt words were said by our outstanding thinkers and poets about a woman, her beauty and tenderness, that she is a symbol of kindness and selflessness, the Keeper of the home. First of all, we once again remember the wise saying of our great ancestor Alisher Navoi "Paradise is at the feet of mothers" and bow down to the sacred image of the Mother with a sense of unpaid duty. A nation that highly values and takes full care of women, creating decent conditions for them, and thus manifests its high culture and spirituality, its unshakable values, certainly deserves the greatest respect. The first President of Uzbekistan I. A. Karimov speaking about the women emphasized: "in our minds all the more strengthened and becomes a philosophy of life the idea that if a woman's life perfect - a beautiful world if a happy woman, a happy family, all of society. Of course, we appreciate that our women have always been the most reliable support in the preservation of families, communities, throughout the country an atmosphere of peace, harmony, mutual respect, and today, thanks to its unique qualities they fill the lives of their families, our life, light, goodness and love" [3, p. 97]. In my article, I want to tell you about two of the greatest women of the East Tamara Khanum and Rosie Karimova, about the life and activities of the heroic and selfless work during the Second world war. Even before the era of television and music videos, Central Asia already had its own ethnic megastar. You could listen to it and watch it in musical performances, where dances, songs and outfits created an irresistible show effect that amazed even the sophisticated audience. Tamara Khanum was called "Eastern Isadora Duncan". The British Queen personally presented the outstanding artist with a high award for her contribution to the arts. The fate of this outstanding woman is somewhat similar to the fairy tale about Cinderella. She had to survive poverty and hunger before becoming famous all over the world. Her name was booming not only in the former Soviet Union, but also far beyond its borders. This Armenian girl from an Uzbek village owed her fabulous popularity to her purposeful character, exceptional hard work and a rare artistic gift. Tamara Khanum was born on March 29, 1906 in a modest family of Anna and Artem Petrosyan, exiled to the Turkestan region, in a small village at the Gorchakovo station (now the city of Margilan). Growing up in an Uzbek mahalla, the girl was not much different from the village children - black-eyed, frisky. When a troupe of traveling artists appeared in the village, they all ran to the performance. Tamara was fascinated by the performances of magicians, 
tightrope walkers, and dancers. At home, she involuntarily repeated the movements of the artists. Each time the awkward steps became more confident, and at the age of six, the girl earned the first applause by dancing in front of her relatives. "You'll see, she'll still dance in Paris!" - somehow proudly remarked the mother, making the audience laugh $[2,1.5]$. But time passed, and a triumphant performance in Paris marked the beginning of a brilliant career of a young dancer. A woman on stage? In those early days, this was unthinkable in the Muslim East. According to the customs of Turkestan, after an early marriage, a woman's life was limited to the "ichkari" - the female half of the house, and the face and body were securely hidden under a burqa and chaste dresses. As Tamara grew older, people increasingly told the petrosyans that Their daughter was behaving inappropriately - after all, she did not think to give up her passion for dancing. The father was even threatened with death if he did not rein in his impudent child. At the end of 1918, Tamara first appeared on the real stage. She was only 12 years old, but she was already performing in front of the audience on a par with the rest. The dance lived in her organically, charged with passion, demanded implementation. Performances at Amateur concerts sharply distinguished the young dancer, she was still the only representative of the fair sex who dared to dance in public, and even with an open face. Threats against Tamara continued, and the parents, out of harm's way, sent their daughter to Tashkent. In 1922, the girl entered the Tashkent ballet company as a student and began dancing in semi-professional concert groups led by the first Uzbek artists: Abror Hidoyatov, Yatim Babadzhanov, Ali Arodobus Ibragimov [2, 1. 6]. Alas, rumors about her "obscene" behavior reached her native village, and local fanatics brutally dealt with her father. The mother was left alone with the children, and the crumbs that Tamara received for performances went to a piece of bread for her relatives. The ballet company has toured in Central Asia, giving concerts of folk dances. In small towns and villages, threats and stones were often thrown at the girl dancer. One performance almost cost Tamara her life: the raging audience was ready to tear her to shreds. Saved one of the artists, a famous musician and wit Yusufjan-Kyzyk. In the confusion, he threw a burqa over her and helped her out of the crowd unnoticed. It required a lot of strength of mind and conviction that they are right not to give up. In 1923, she went to Moscow to continue her education at the Lunacharsky Theater technical school. The Moscow audience compensated for all the unpleasant moments of the first performances, meeting the art of the young talent with excitement. It was in Moscow that she received her second metaphorical name - "swallow of the East". It happened that particularly persistent fans made their way backstage after the concert to personally Express their delight. So when one of these guys showed up in the dressing room and complimented her, Tamara wasn't surprised. It turned out to be a famous singer Mukhitdin Kari-Yakubov. After introducing him, the Manager told her: "Now you will perform together." Then she did not assume that "together" - will be forever: Mukhitdin became her husband, the father of a daughter. The young couple went on their first trip abroad, to France. In 1925, the world exhibition of decorative art was held in Paris. Mukhitdin Kari-Yakubov and Tamara had the honor to represent their region. Their number was a stunning success, and Parisians remembered Uzbek artists for a long time. Returning home, the couple passed through Germany, where the famous dancer Isadora Duncan wanted to meet Tamara. She asked Tamara to let her touch and count the vertebrae, proving that with a normal body structure, a person is not capable of such incredibly complex and beautiful movements. Tamara enjoyed wide recognition and fame at the age of 19. After her success in Paris, the whole world opened up to her. She has traveled half the world, and there are countless countries where her little feet have danced. After one funny story, the pseudonym Khanum was firmly established for 
her. It so happened that before a major concert in Moscow, one of its organizers heard her fellow countrymen call Tamara "Khanum" (woman). The next day, posters with the name "Tamara Khanum" were hung all over the city. Foreigners could not understand, what is the nationality of this amazing dancer. An Armenian by blood, who grew up in the Uzbek mahalla, Khanum brought home a new dance from each trip, reincarnating in it with great power. In her creative piggy Bank gathered dances of 86 peoples of the world.

In 1938, she made a revolution in the performing arts, combining two genres-song and dance. Now the artist also sang in many languages, and without an accent, completely getting used to the created image. "As soon as I take a step out of the wings to meet the audience," she said, " I physically feel thousands of invisible threads that quickly arise between me and the audience. The more of these threads, the better my voice sounds, as if I am possessed by thousands of demons, who create my dance, " she admitted. This expression, obsession with what she loved, extraordinary hard work, and God-given talent kept her at the top of everyone's respect and admiration for many years. In 1935, at the International dance festival in London, the British Queen personally presented the artist with a high award for her contribution to the arts.

During the great Patriotic war, Tamara Khanum performed concerts all over the front, from the Pacific ocean to Europe, for which the military command awarded her, the only artist, the title of captain and gave her the right to bear arms [11, 1.174]. Heads of state, prominent politicians, artists, and public figures were honored to see Tamara Khanum perform and get to know her personally. The composer Isaac Dunaevsky wrote: "You invite me to Sunny Uzbekistan. Thanks! But any country, any place where You and your wonderful art are located will be Sunny!"[7, 1. 3].

Having accumulated creative experience, in 1930 the famous artist tries her hand as a choreographer. In 1932, in collaboration with Director Z. Kabulov and composer P. Rakhimov, she organized a theater in Urgench, where she performed simultaneously as a ballet master, dancer, and teacher-tutor. On her initiative, the school of classical ballet was opened in Tashkent. Optimism, a sense of humor and fortitude helped her to preserve her beauty for a long time. Until her old age, she toured the world without losing any bubbling energy or flexibility of movement. Cheerful, kind-hearted by nature, she attracted people to her like a magnet. Tamara Khanum died in 1991, in Tashkent, having bequeathed to make a Museum in her house, where thousands of stage costumes in which she performed would be stored. Each of them, embroidered with gold and silver threads and precious stones , is an example of art in itself. The Tamara Khanum Museum opened in 1994. He preserved the interiors of living rooms, costumes, recordings of songs, a magnificent collection of paintings, gifts, photographs and manuscripts of an outstanding artist. Among them are unpublished memoirs, as well as poems created already in the period of wisdom, in the declining years. In one of them, Tamara Khanum plays the lines of Omar Khayyam: "what Fate has come to give you, you can't help but moderate and take away...". This truly great woman was the epitome of intelligence, grace, beauty and perseverance. Rozia Zarif-kizi Karimova is an Uzbek ballet dancer, performer of Uzbek folk dances, choreographer, singer, teacher, art critic, expert and founder of the theory of Uzbek dance. People's artist of Uzbekistan, knight of orders. Author of 17 books and textbooks on the history and theory of Uzbek dance. Rozia Karimova was born in 1916 in Kazan in the family of a merchant. Unfortunately, Rosie and her older sister, Sarah, were orphaned early and raised by their grandmother. Then, by the will of fate, both girls came to Uzbekistan, to the Ferghana valley. Rosia was accepted to the children's home in Margilan [2, p. 163]. 
Since childhood, the girl loved to sing and dance, actively participated in school Amateur performances. There she was first seen by Mukarrama turgunbayeva (later the Creator and Director of the famous dance ensemble "Bahor"), who became a mentor and older friend for Rozia for life.

In the 20s of the last century in Central Asia, despite the unfolding struggle for the emancipation of Muslim women, there were still very few female Actresses, so Rosie was not easily given the decision to devote herself to art. In 1930, rozia entered the newly created theater Studio under the direction of Mukhitdin Kara-Yakubov at the Uzbek state music and drama theater in Samarkand and soon became a soloist of this theater. From that time on, she performed lyrical and heroic dances and played dramatic roles on stage: Azadkhon ("Ichkarida" by yashen and Mukhamedov, 1932), Anarkhon ("comrade" by yashen, 1930), ASAL ("Gulsara" by yashen, Muz. Jalilova, 1935), Asia ("Arshin Mal Alan"). Here she is engaged in classical dance with Alexander Ben, Usta Alim Kamilov. In the Studio has taught such famous masters: Yusufjon kizikum of Scenarionow, Gavkhar Rakhimova, Mutawwakil of Burhonov, Kamil Yashen, Tamara Khanum. Thus, rozia received a very thorough musical and choreographic education by the standards of that time and was enrolled in the dance troupe of the Uzbek musical theater. After that, in the period 1934-1949 at the Tashkent musical theater, and from 1949 to 1953 - at the Opera and ballet theater named after A. Navoi, she performed the main roles of Gulyandom (E. Brusilovsky, "Gulyandom", 1940), AK-Belyak (S. Vasilenko, "AK-Belyak", 1943) [8, 1. 329], Frasquita (J. Bizet "Carmen"), Kumysh-OI ("Buran" Ashrafi and Vasilenko). In such operatic works as "Comrades", "Buran", "Gulsara", "Ulugbek", "Farhad and Shirin", "Leyli and Majnun" she staged and skillfully performed solo dances. Rozia Karimova's long and truly brilliant creative career began there. Growing up in Margilan, in the very heart of Uzbekistan, under the guidance of mentors, rozia mastered and constantly honed the techniques and plasticity of purely Uzbek dance.

As part of the theater troupe, she tours Uzbekistan, participates in all significant concerts: on the occasion of the completion of the Great Ferghana canal, the Farhad hydroelectric power station, etc. [1, p. 217]. She is invited to participate in special events on the occasion of public holidays and memorable dates. Rozia, as part of a group of artists, represented Uzbek dance art in Moscow (1937) at the Decade of Uzbek literature and art. Her dancing on the stage of the Bolshoi theater was applauded by Stalin. High musical culture, refinement and filigree of every element, every gesture, knowledge of the style of movement of Uzbek dances in each region of Uzbekistan, combined with a dazzling appearance and femininity caused admiration of the audience, and being very young rozia Karimova entered the galaxy of the most remarkable, most famous dancers, such as Mukarrama turgunbayeva, Halima Rakhimova, Gavhar petrosova, Maryam Yakubova, Tamara Khanum. Thanks to their creativity, in the 30s, Uzbek folk dance acquired stage features [12, p. 170]. Their activities, their creative searches are important for raising the prestige of the dance art on the concert stage. Perhaps for the first time, the General public began to treat non-theatrical dance as a serious art. This respect was shown not only in the huge attention of the audience and the Central press, which widely covered the tour, but also in providing dancers with the best stage venues in Uzbekistan and abroad. The performance of ballet parts is characterized by dramatic expressiveness, a combination of techniques of Uzbek folk dance with pantomime. Since the 40s, rozia Karimova has been working as a choreographer, putting dances in performances of the Uzbek musical theater. Mukimi, for the stage [9, 1. 114]. Rosia successfully combines active creative activities with family responsibilities. She has a loving husband - Nasrullo Okhundi-a famous poet and prose writer, in the pre-war years one of the leaders of the Union of writers 
of Uzbekistan. In 1933, his son Marat (now a candidate of technical Sciences, a well-known scientist) was born. Rosia is the owner of a large hospitable house, where famous cultural figures, artists, and writers often visited. Her older sister, Sarah, who became editor of the newspaper Lenin uchkuni (Iskra), along with her husband, a major government official, have also always been a reliable support in Rozia's life.

All creative and life plans were disrupted by the war. Trains with evacuees and wounded began to arrive in Tashkent. Many artists thought that their work in the arts was over and were ready to do any other work that their Homeland needed at that time. But it turned out that during the harsh war years, art has a strong emotional and ideological impact on the audience, which is in dire need of bright and joyful impressions. Tamara Khanum has already left for the front with her ensemble [6, 1. 4]. Then a special team of artists was created under the leadership of Gavkhar Rakhimova. And during the great Patriotic war, rozia Karimova, as part of artists from Uzbekistan, performed concerts in hospitals and in front of red Army soldiers, first in hospitals in Tashkent, Urgench, Bukhara, and then on the fronts, including on the North-Western front [4, 1. 3]. the Stage platform was a trampled piece of land or the body of a lorry, but invariably the appearance of artists, and even in national clothes, their songs and dances, caused inspiration and had an extraordinary success. The wartime gave a new impetus to the development of art, and in particular the art of dance, suggesting new forms of their implementation.

For the artistic group, which included rozia Karimova, in concerts at the front, the main program song was the song "Forward", written by the composer Pulatjon Rakhimov to the poems of Rozia's husband, Nasrullo Ohundi. In 1943, as part of a group of masters of Uzbekistan, she participated in a solemn concert before the heads of the countries of the anti-Hitler coalition.Roosevelt, W. Churchill and I. Stalin, and other participants of the conference in Tehran. A number of other concerts were given with the participation of Uzbek artists [5, 1. 3].

After the war, rozia continued her creative activity on the stage of The Uzbek state Opera and ballet theater named after A. Navoi. Even in the years of her apprenticeship, she revealed versatile talents. She was equally capable of both characteristic and classical dance, and she also had an outstanding singing talent. As a result of the development and detailed study of the diversity of dance folklore in Uzbekistan, based on its own rich performing experience, rozia begins to seriously think about the need to create a special theory of stage interpretation of folk dance, in order to preserve it as a cultural heritage item, on the one hand, and on the other with the aim of using its elements in larger theatrical productions. At the same time, there is a need to review the training programs for dancers in choreographic schools and other educational institutions in order to bring the teaching of characteristic dances closer to the authentic sources of Uzbek folk choreography. To this end, she began teaching Uzbek folk dances at the Tashkent choreographic school in 1932. In 1935-1960, working as a choreographer and at the same time as a soloist of the Uzbek State musical theater of drama and Comedy named after Mukimi, she staged and masterfully performed dances in such performances as" Nurkhon"," Ravshan and zulhumor"," Tahir and Zuhra"," Oftobkhon"," OK Nilufar"," Zafar " and others [12, p.16]. Rozia Karimova is not only a talented dancer, she is also a skilled teacher and researcher of the theoretical and practical foundations of dance art.

Until now, Uzbek dance existed only in the memory of its performers and spectators. Rosia was the first to dare and implement her idea of creating full-fledged textbooks. For the first time in history, she recorded Uzbek dance as a choreographic work, described, designated and created a unique system 
of movements, positions, and gestures. She gave information about the features of choreography and performance skills, about the signs of the costume, the design of the number, and about the musical material. Rozia Karimova was engaged in systematization and scientific generalization of the main provisions, movements, and rhythms of Uzbek folk dance. There are three schools in Uzbek folk dance: Ferghana, Khorezm, and Bukhara. each school has its own clothes [13, p. 173]. Based on the rich experience of masters of the dance style, R. Karimova prepared textbooks "Ferghana dance" (1973), "Khorezm dance" (1975), "Bukhara dance" (1977), as well as books "dances of the "Bahor" ensemble, "Doira zarblariga mashgulot" ("drumming Classes"), "Dances of Uzbekistan", "dances of Rabia Atajanova". Rozia Karimova's works have received the most positive reviews and reviews from famous dancers and theater experts in Uzbekistan, and for several decades they have been a reference book for teachers and students, future dancers.

The government of Uzbekistan highly appreciated the services of Rozia Karimova. Her outstanding contribution to the development of the theory of domestic choreographic art of Uzbek dance. During the years Of independence of Uzbekistan, rozia Karimova received the title of people's artist of Uzbekistan, the "El-Yurt khurmati" medal, and the degree of honorary doctor of art history. Under the guidance of Rozia Karimova, many bright talents studied, who themselves have already been awarded honorary artistic titles and government awards. Rozia Karimova is considered a mentor by Bernard karieva, Rayno Nizamova, Ibragim Yusupov, Dilafruz Jabbarova, Shokir Akhmedov, Dilbar Abdullayeva, Karima Uzokova, sivilya Tangurieva, Kadyr Muminov. Today, many followers of Tamara Khanum, Mukarrama turgunbayeva, and Rozia Karimova contribute to the development of the art of dance. They work productively in the dance theatre "Ofarin", dance collectives "Sabo", "Uzbegim ulduzlari", "Uzbegim esleri" and others. Rozia Karimova passed away on March 15, 2011 and was buried at the Minor cemetery in Tashkent. Rozia Karimova emphasized that the greatest value in the life of every person is peace on earth, family, close and dear people, and love for the Motherland.

\section{REFERENCES:}

1. The history of the Uzbek Soviet music. Vol. 1. (1917-1945). -T.: 1972. -S. 380.

2. History of Uzbek music. -M.: Muzyka,1979. -S. 200.

3. Karimov I. A. the Great spirituality - an invincible force. -T: 2008. - $176 \mathrm{~b}$.

4. Red Uzbekistan, 1942. January 1.

5. Red Uzbekistan, 1942. December 8.

6. Red Uzbekistan, 1943. March 27.

7. Red Uzbekistan, 1943. September 15.

8. CGA RUz, f. R-94, op. 5, D. 4578. L. 329.

9. CGA RUz, f. 2087, op.1, d. 89, 1. 114.

10. CGA RUz, f. 2087, op.1, d. 91, 1. 5-6.

11. CGA RUz, f. 2087, op.1, d. 86, 1. 174.

12. CGA RUz, f. 2087, op.1, d. 100, 1. 16.

13. Ergasheva Yu. a. Culture of Uzbekistan: trends and problems of development.Tashkent: 1997. - $210 \mathrm{p}$.

14. Ergasheva Yu. a. Culture of Uzbekistan: trends and problems of development.Tashkent: 1997. - 210 p. 